\title{
Quantitative Predictions for the Position and Height of Berms
}

\author{
Sei-ichi OKAZAKI* and Tsuguo SUNAMURA**
}

\begin{abstract}
Using experimental results on berms created in a small-scale wave flume, the position and height of berms in an equilibrium state were examined. The berm position, $X$, which is defined as the horizontal length from the shoreline to the berm crest, was found to be expressed by: $X /\left(g T^{2}\right)^{3 / 8} H_{b}^{5 / 8} \phi=0.605$ and 0.305 for collapsing related berms and for surging related berms, respectively, where $H_{b}$ is the breaker height, $T$ is the wave period, $g$ is the gravitational acceleration, and $\phi$ is the reduction factor due to the roughness and permeability of the beach. The reduction factor was given by $\phi=\exp \left(-0.04 D_{*}^{0.55}\right)$, where $D_{*}$ is the dimensionless grain diameter of sediment, $D_{*}=\left[g\left(\rho_{S} / \rho-1\right) / v^{2}\right]^{1 / 3} D, D$ is the sediment diameter, $\rho_{S}$ is the sediment density, $\rho$ is the fluid density, and $v$ is the kinematic viscosity of fluid. The berm height, $B_{h}$, was given by: $B_{h} /\left(g T^{2}\right)^{5 / 8} H_{b}^{1 / 8} D^{1 / 4} \phi=0.117$ and 0.067 for the collapsing related berms and for surging related berms, respectively. Analyses of the existing prototype-scale experiment data indicated that no scale effect is involved in these laboratory relations as far as collapsing related berms are concerned.

Time-series data of the beach profile obtained at Ajiga-ura Beach, Ibaraki, Japan, were used for the examination of applicability of these relations to the field situation, where collapsing related berms developed. The height of the mean high waters was used as a reference level in measuring the berm position and height. The breaker height, $\bar{H}_{b}$, and wave period, $\bar{T}$, of mean waves averaged over the period of berm development were substituted respectively for the wave characteristics in the laboratory-based equations. The berm position, $X^{\prime}$, was described by $X^{\prime} /\left(g \bar{T}^{2}\right)^{3 / 8} \bar{H}_{b}^{5 / 8} \phi=1.14$ and the berm height, $B_{h}^{\prime}$, was expressed by $B_{h}^{\prime} /\left(g \bar{T}^{2}\right)^{5 / 8} \bar{H}_{b}^{1 / 8} D^{1 / 4} \phi=0.134$.
\end{abstract}

Key words: berm height and position, roughness and permeability of the beach, scale effect, applicability to the field.

\section{INTRODUCTION}

A berm is a substantial sand or shingle body accumulated on the landward portion of beach profile and is a typical depositional landform on sandy or shingle beaches. Since the berm crest usually runs parallel to the general shoreline trend, the berm may be characterized by a two-dimensional morphology in the foreshore zone.

Using a wave tank, BAGNOLD (1940) first carried out laboratory experiments on the formation of berms. Since then, several quantitative studies on the size of berms have been performed (e.g., BASCOM, 1953; RECTOR, 1954; KING, 1959, p. 189; SUNAMURA, 1975; TAKEDA and SUNAMURA, 1982; LARSON, 1988). The experimental result of BAGNOLD showed that the height of berms is simply proportional to the wave height, i.e., $B_{h}=\alpha H^{\prime}$, where $B_{h}$ is the height of berms above Still Water Level, $H^{\prime}$ is the difference between the crest level of offshore waves and the level of the lowest exposed beach line, and $\alpha$ is a coefficient with the value depending on the sediment diameter. BAGNOLD noted explicitly the dependence of the berm height on the sediment diameter.

Considering BAGNOLD's results, BASCOM (1953) proposed the following equation, introducing the effect of wave refraction: $B_{h}=1.3 K_{r} H_{0}$, where $K_{r}$ is the refraction coefficient and $H_{0}$ is the deep-water wave height. Based on her experimental results, KING (1959, p. 189) also found a linear relationship between the berm height and the deep-water wave height.

From his experimental results, RECTOR (1954) obtained the following relationship, which is described not only by wave height but also by wavelength: $B_{h}=0.18\left(H_{0} L_{0}\right)^{1 / 2}$, where $L_{0}$ is the deep-water wavelength. Using available experimental data, SUNAMURA (1975) also obtained the relationship: $B_{h}=0.09 H_{0}^{3 / 10} L_{0}^{7 / 10}$.

An analysis of experimental data by TAKEDA

* Research student, Department of Geosphere Environments, Graduate School of Science, Tohoku University, Sendai 980-77, Japan

** Institute of Geoscience, University of Tsukuba, Ibaraki 305, Japan 
and SUNAMURA (1982) led to the relationship: $B_{h}=$ $0.125\left(g T^{2}\right)^{3 / 8} H_{b}^{5 / 8}$, where $T$ is the wave period, $g$ is the gravitational acceleration, and $H_{b}$ is the initial height of breaking waves. They attempted to apply this relation to the field and obtained reasonable results.

Recently prototype-scale experiments on beach changes using a large wave flume have been conducted and high-quality data have accumulated (eg., KAJIMA $e t$ al., 1982; KRAUS and LARSON, 1988). Berm studies through these experiments have not been carried out. Only LARSON (1988) proposed the following berm height relation using prototype-scale experiment data: $B_{h}=$ $1.47 H_{0}\left(\tan \beta / \sqrt{H_{0} / L_{0}}\right)^{0.79}$, where $\tan \beta$ is the initial, uniform beach slope.

The previous studies on the berm height have left a basic problem unsolved. BAGNOLD (1940), SUNAMURA (1975) and TAKEDA and SUNAMURA (1982) discussed the influence of grain size of beach material on the berm height. But, their conclusions are different from each other. Bagnold described the dependence of the berm height on the sediment diameter, whereas the other two concluded that the berm height is independent of sediment size. Since a berm is formed on sandy or shingle beaches, the roughness and permeability of the beach should control the berm height.

In the field some berms develop very near the shoreline, and others considerably far from it. This fact shows that the position of berm crest would depend on the characteristics of incoming waves and, possibly, of beach sediment. In contrast to many studies on the height of berms as described above, no quantitative studies concerning the berm position have been made even in the laboratory environment.

On the basis of the results of small-scale laboratory experiments, this study attempted to explore the relationships concerning the berm position and height. The applicability of the results to the field was investigated after the examination of scale effect using the prototype-scale laboratory data.

\section{WAVE RUN-UP ON PERMEABLE, UNIFORM SLOPES}

Because wave run-up processes are responsible for the position and height of berms, general properties of wave run-up should be examined prior to the investigation of the present problems. It is well known that the height of wave run-up on actual beaches is closely associated with the roughness and permeability of the beach. HUNT (1959) presented a general formula for the height of the run-up of monochromatic waves breaking on a permeable, uniform slope:

$$
R=1.016\left(H_{0} L_{0}\right)^{1 / 2} \phi \tan \beta
$$

where $R$ is the run-up height, $\beta$ is the slope angle, and $\phi$ is the reduction factor due to the roughness and permeability of the slope. The reduction factor was defined by HUNT as the ratio of wave run-up height on a porous, permeable slope to that on a smooth, impermeable slope with the same gradient. When $\phi=1$, Eq. (1) represents the height of wave run-up on a smooth, uniform, impermeable slope.

Concerning the roughness and permeability of the slope, SAVAGE (1958) and Tsuchiya et al. (1978) attempted to quantify the reduction ratio on the wave run-up height, but they did not formulate it. Using the data cited in HUNT (1959), TERADA (1976) suggested that the reduction factor $\phi$ decreases linearly with increasing grain size of sediment. Because $\phi$ is a dimensionless quantity, the grain size parameter should be nondimensional.

To describe the sediment mobility within the stream bed, SHIELDS (1936) obtained two dimensionless parameters: the tractive tension coefficient, $Y_{*}=\tau /\left(\rho_{S}-\rho\right) g D$, and the grain Reynolds number, $X_{*}=U_{*} D / v$, where $D$ is the sediment diameter, $\rho_{S}$ is the sediment density, $\rho$ is the fluid density, $v$ is the kinematic viscosity of fluid, $U_{*}$ is the shear velocity and $\tau\left(=\rho U_{*}^{2}\right)$ is the shear stress. According to YALIN (1977, p. 67), a parameter $\Xi$, first described by YALIN and RUSSELL (1962), is given from a combination of $X_{*}$ and $Y_{*}$ as follows: $\Xi=X_{*}^{2} / Y_{*}=$ $g\left(\rho_{S} / \rho-1\right) D^{3} / v^{2}$. The cube root of $\Xi$ is expressed as

$$
\Xi^{1 / 3}=\left[g\left(\rho_{S} / \rho-1\right) / v^{2}\right]^{1 / 3} D=D_{*}
$$

The parameter $D_{*}$ is the dimensionless grain diameter of sediment, as already described by ACKERS and WHITE (1973).

The reduction factor $\phi$ was obtained in this study applying the experimental results of SAVAGE (1959). SAVAGE used a uniform model beach with gradients ranging from $1 / 30$ to $1 / 4$ set up in a small wave flume. Wave run-up height was measured on a smooth, impermeable slope and also on five kinds of porous, permeable slopes, composed of granular materials with a diameter of $0.2,1,2,3.5$ and $10 \mathrm{~mm}$.

Figure 1 plots the relationship between $\phi$ and $D_{*}$. For the calculation of $D_{*}$, the following equation was used:

$$
D_{*}=251.3 D \quad \text { (in cm units) }
$$

This was obtained by substituting $g=980.7 \mathrm{~cm} / \mathrm{sec}^{2}$, 


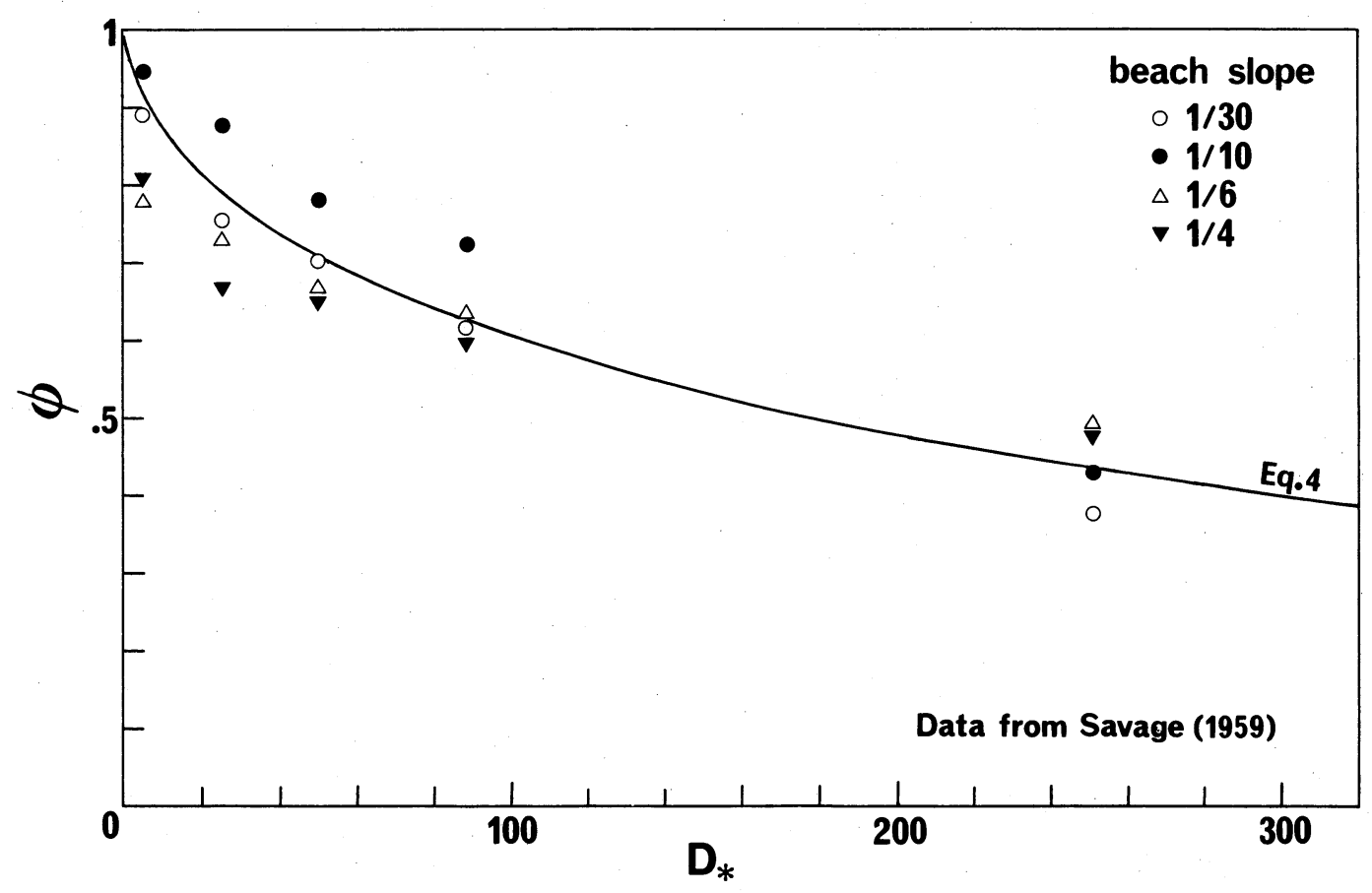

Figure 1. Relationship between reduction factor and dimensionless sediment diameter.

$\rho_{S} / \rho=2.65$ and $\nu=1.01 \times 10^{-2} \mathrm{~cm}^{2} / \mathrm{sec}$ (at a water temperature of $20^{\circ} \mathrm{C}$ ) into Eq. (2). Assuming no systematic dependence of $\phi$ on beach slope, a general trend showing the $\phi$ vs. $D_{*}$ relation is given by

$$
\phi=\exp \left(-0.04 D_{*}^{0.55}\right)
$$

\section{SMALL-SCALE LABORATORY EXPERIMENT}

\section{Wave-flume experiment and results}

The present laboratory experiment was conducted using a wave flume, $12 \mathrm{~m}$ long, $0.2 \mathrm{~m}$ wide, and $0.4 \mathrm{~m}$ deep, equipped with a plunge-type monochromatic wave generator. A filter made of folded stainless steel meshes was installed in front of the wave generator to filter out reflections from the beach. A model beach with a $1 / 10$ gradient was set up in the flume and water depth at the horizontal part was $0.25 \mathrm{~m}$. Five kinds of well-sorted sand $(D=0.22,0.69,1.3,2.4$ and $5.2 \mathrm{~mm})$ were used for beach material. Five kinds of wave period $(T=1.8,2.0$, $2.2,2.4$, and $2.8 \mathrm{sec}$ ) were selected, and the initial height of breaking waves ranged from 5.2 to $9.9 \mathrm{~cm}$ (Table 1).

Waves were allowed to act until an equilibrium state of beach profile was attained, i.e., until the changing rate of beach profile became small. The time required for it ranged from thirty minutes to one hour depending on experiment runs. The beach profile was measured along the center line of the flume by an automatic profiler every five minutes as a general rule.

This study employed the breaker-type criterion of GALVIN (1968) to classify breaking waves into four types: spilling, plunging, collapsing and surging breakers. On the basis of breaker types appearing in an equilibrium state, OKAZAKI (1994) classified the type of berms into three: collapsing, surging, and quasi-surging related berms. In the present study, the former two types will be treated, because significant change of beach profile occurred.

These are illustrated in Fig. 2, which shows overall beach profiles and related flow patterns observed in an equilibrium beach state. For these types of berms, the marked change in the initial, uniform bottom slope occurred in the shoreward region of the first antinode (denoted as "F.A.") of standing waves which appeared as an equillibrium state attained.

The beach profile with a collapsing related berm (Fig. 2a) is characterized by the presence of a pronounced step at the seaward edge of the beach face. The step is maintained by the action of the marked backwash vortex; the vortex disappears with the approach of a next incident wave and the wave collapses over the step. The 
Table 1. Experimental condition and results (notation explained in text).

\begin{tabular}{|c|c|c|c|c|c|c|}
\hline Case & $\underset{(\mathrm{mm})}{D}$ & $\begin{array}{c}T \\
(\mathrm{sec})\end{array}$ & $\begin{array}{c}H_{b}^{*} \\
(\mathrm{~cm})\end{array}$ & $\begin{array}{c}X \\
(\mathrm{~cm})\end{array}$ & $\begin{array}{c}B_{h} \\
(\mathrm{~cm})\end{array}$ & Type of berm \\
\hline 1 & 0.22 & 2.4 & 7.2 & 47.5 & 9.2 & Collapsing related berm \\
\hline 2 & & 2.4 & 9.5 & 59.1 & 11.5 & ditto \\
\hline 3 & & 2.8 & 7.9 & 57.0 & 9.4 & ditto \\
\hline 4 & 0.69 & 2.4 & 7.2 & 44.1 & 9.9 & ditto \\
\hline 5 & & 2.8 & 7.9 & 53.2 & 11.1 & ditto \\
\hline 6 & 1.3 & 2.2 & 9.8 & 46.2 & 16.6 & ditto \\
\hline 7 & & 2.4 & 7.2 & 20.0 & 10.6 & Surging related berm \\
\hline 8 & & 2.4 & 9.5 & 26.5 & 11.1 & ditto \\
\hline 9 & & 2.4 & 9.9 & 43.5 & 13.6 & Collapsing related berm \\
\hline 10 & & 2.8 & 7.9 & 24.9 & 11.1 & Surging related berm \\
\hline 11 & 2.4 & 2.2 & 5.2 & 8.7 & 5.3 & ditto \\
\hline 12 & & 2.4 & 7.2 & 18.3 & 9.9 & ditto \\
\hline 13 & & 2.8 & 7.9 & 17.7 & 10.7 & ditto \\
\hline 14 & 5.2 & 1.8 & 7.1 & 12.7 & 4.5 & ditto \\
\hline 15 & & 2.0 & 8.7 & 16.4 & 9.7 & ditto \\
\hline
\end{tabular}

* Value at the initial stage.

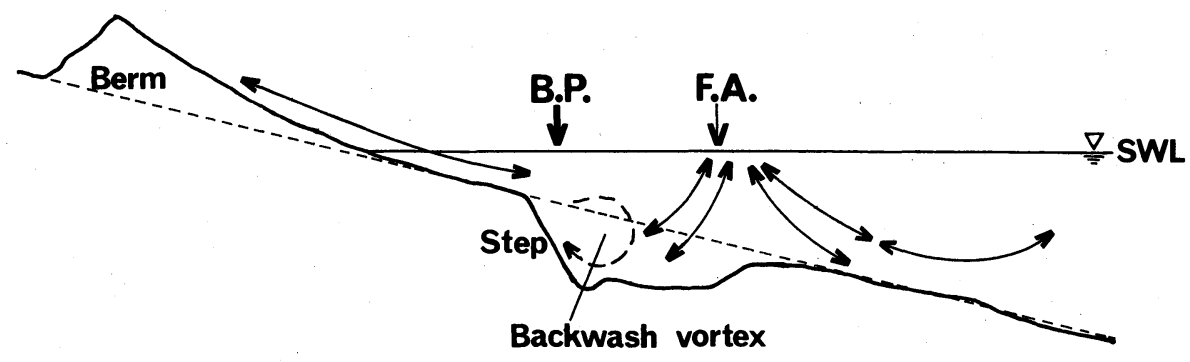

(b) Beach profile with surging related berm

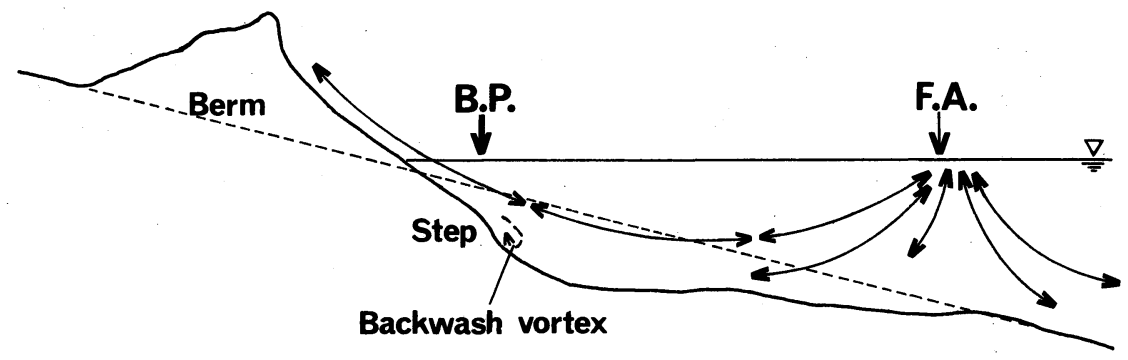

Figure 2. Schematic diagram showing beach profiles and flow patterns of water particles for (a) collapsing related berm and (b) surging related berm.

"B.P." denotes the breaking point and "F.A." the first antinode of standing waves. After ОКАZАKI (1994). 
beach profile with a surging related berm (Fig. 2 b) has a step-like morphology with less significant topographic break. In an equilibrium beach state, waves slid up and down the beach face with little bubble production.

As these two types of berms grow, the wave breaking point shifts shorewards (OKAZAKI, 1994). Figure 2 shows the terminal breaking point in an equilibrium state denoted as "B.P.", which is close to the seaward edge of the beach slope.

\section{Predictive relation for berm position}

Because the breaker height $H_{b}$ is directly responsible for the nearshore bottom profile, this study was performed on the basis of $H_{b}$ in place of the deep-water wave height $H_{0}$. The height of breaking waves varies slightly with time for collapsing related berms, and considerably for surging related ones, as the beach profile changes. At the final stage, reflection waves affect the value of breaker height. Therefore the height of breaking waves at the initial stage was employed as $H_{b}$ in the present study.

Concerning the relationship between the breaker height and the deep-water wave characteristics, KOMAR and GAUGHAN (1972) proposed the following semiempirical equation which is based on the conservation of the energy flux of linear waves:

$$
H_{b} / H_{0}=0.563\left(H_{0} / L_{0}\right)^{-1 / 5}
$$

Using Eq. (5) and the well-known relationship between the deep-water wavelength and the wave period, $L_{0}=g T^{2} / 2 \pi$, Eq. (1) can be transformed as

$$
\begin{aligned}
& R=0.731\left(g T^{2}\right)^{3 / 8} H_{b}^{5 / 8} \phi \tan \beta \\
& R / \tan \beta=0.731\left(g T^{2}\right)^{3 / 8} H_{b}^{5 / 8} \phi
\end{aligned}
$$

The right side of Eq. (6b) represents the horizontal length from the shoreline to the run-up limit of monochromatic waves breaking on a uniform slope. The quantity $\left(g T^{2}\right)^{3 / 8} H_{b}^{5 / 8} \phi$ is independent of beach slope angle, so that this quantity becomes significant as a scaling parameter when we consider the berm position.

The two types of berms showing significant topographic change (Fig. 2) will be treated here. Using the experiment data, the relationship between $\left(g T^{2}\right)^{3 / 8} H_{b}^{5 / 8} \phi$ and $X$ was examined (Fig. 3), where $X$ is the horizontal length from the shoreline to the berm crest in an equilibrium state. Eq. (4) was used to obtain the value of $\phi$. Figure 3 shows that the normalized berm positions are respectively constant for two berm types:

$$
X /\left(g T^{2}\right)^{3 / 8} H_{b}^{5 / 8} \phi=0.605
$$

for collapsing related berms, and

$$
X /\left(g T^{2}\right)^{3 / 8} H_{b}^{5 / 8} \phi=0.305
$$

for surging related berms.

\section{Predictive relation for berm height}

Eq. (6a) indicates that the run-up height depends on beach slope angle. When a berm attains an equilibrium morphology, waves break close to the seaward edge of beach slope (Fig. 2); the beach-face slope seems to be very important for the wave run-up process in the swash zone.

Figure 4 plots the relationship between $H_{b} /\left(g T^{2}\right)^{1 / 2} D^{1 / 2}$ and $\tan \alpha$, the beach-face slope when an equilibrium berm develops: $\tan \alpha$ is the gradient of the tangent line at the SWL intersection and $H_{b}$ is the breaking wave height at the initial stage. The solid curve indicates SunAMURA's (1984) relation in the field:

$$
\tan \alpha=0.12\left(g T^{2}\right)^{1 / 4} D^{1 / 4} / H_{b}^{1 / 2}
$$

Beach profiles defined as "berm-step" in YoKOTSUKA (1985), data of which are plotted by square symbols in this figure, can be reckoned as collapsing related berms, judging from time-series data of her beach profiles.

Figure 4 shows that Eq. (9) can describe the general trend of the data points. Assuming $\tan \beta=\tan \alpha$ and replacing $R$ by $R^{\prime}$ in Eq. (6a), and using Eq. (9) one obtains

$$
R^{\prime}=0.0877\left(g T^{2}\right)^{5 / 8} H_{b}^{1 / 8} D^{1 / 4} \phi
$$

It may be assumed that the berm height, $B_{h}$, is proportional to $R^{\prime}: B_{h} \sim\left(g T^{2}\right)^{5 / 8} H_{b}^{1 / 8} D^{1 / 4} \phi$.

In order to explore the relationship between these two quantities, the present experiment data (Table 1) plus the previous ones of TAKEDA and SUNAMURA $(1982)^{1)}$ and YокоTSUKA (1985) were employed. In all these experiments, the breaker height was measured. Figure 5 shows the relationship between $B_{h}$ and $\left(g T^{2}\right)^{5 / 8} H_{b}^{1 / 8} D^{1 / 4} \phi ; B_{h}$-values were obtained from the equilibrium beach profile and $H_{b}$ was a value at the initial stage. Data of Type-II berms (TAKEDA and SUNAMURA, 1982), plotted by triangular symbols in this figure, seem to correspond to collapsing related berms, judging from their profiles (TAKEDA and SUNAMURA, 1983).

The heights of two types of berms are approximated by the two linear lines, respectively (Fig. 5). For collapsing related berms (open symbols), the height is given by:

$$
B_{h} /\left(g T^{2}\right)^{5 / 8} H_{b}^{1 / 8} D^{1 / 4} \phi=0.117
$$




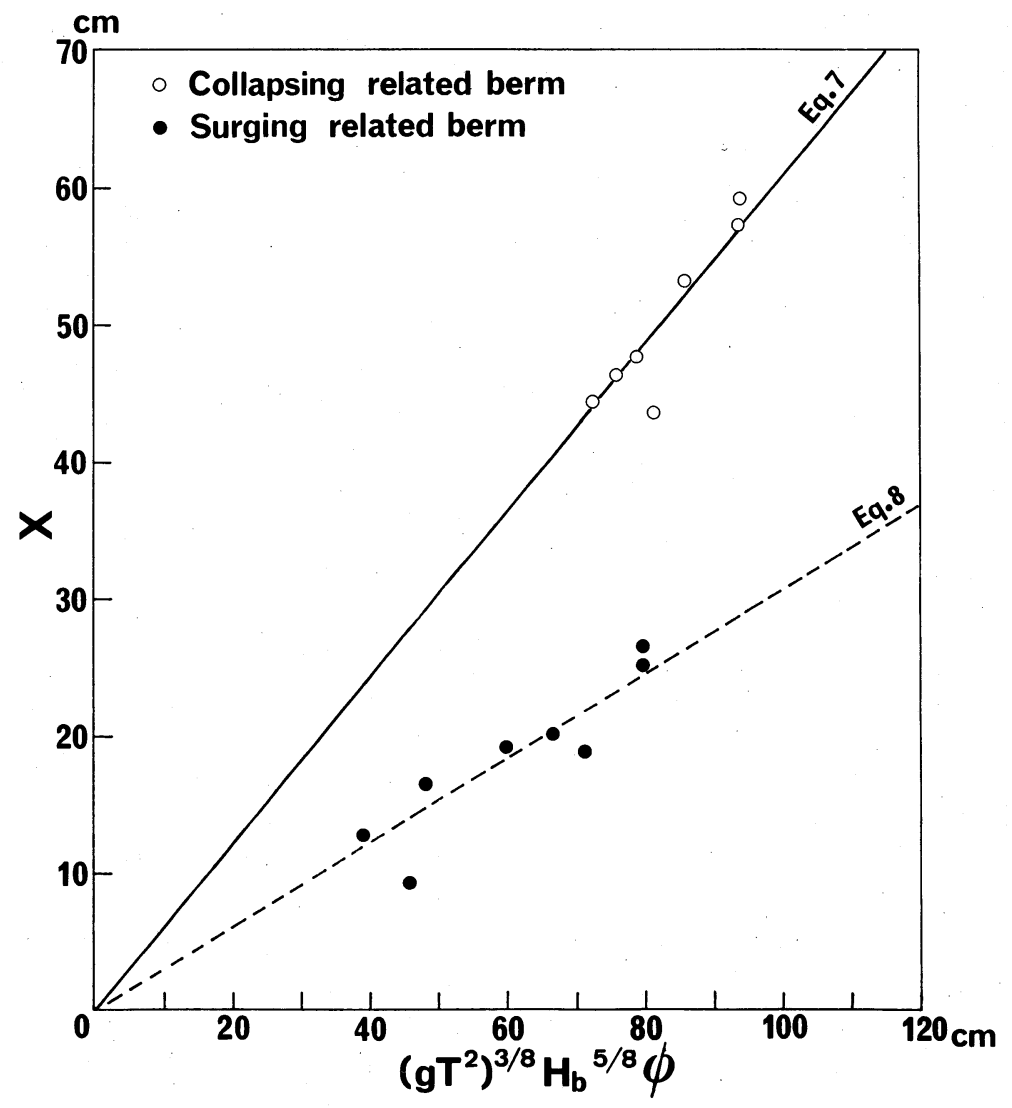

Figure 3. Position of berms created in a small-scale wave flume.

The solid line shows an empirical relation for collapsing related berms and the dashed line for surging related berms.

For surging related berms (closed symbols), the height is described as

$$
B_{h} /\left(g T^{2}\right)^{5 / 8} H_{b}^{1 / 8} D^{1 / 4} \phi=0.067
$$

although data are limited in number.

\section{INVESTIGATIONS USING PROTOTYPE-SCALE EXPERIMENT DATA}

KRAUS and LARSON (1988) pigeonholed data of prototype-scale experiments on beach change conducted by the U.S. Army Corps of Engineers during 1956-57 and 1962, using a wave tank (114 m long, $4.6 \mathrm{~m}$ wide, and $6.1 \mathrm{~m}$ deep) with a piston-type monochromatic wave maker. An initial beach slope with a uniform gradient of $1 / 15$, made of quartz sand with a median diameter of $0.40 \mathrm{~mm}$, was set up. Water depth at the horizontal part in the flume was $3.8,4.3$ or $4.6 \mathrm{~m}$. Two kinds of wave period ( $T=11.3$ and $16.0 \mathrm{sec})$ were employed, and the initial height of breaking waves ranged from 1.77 to $3.05 \mathrm{~m}$. A duration of wave action was thirty to fifty hours, depending on experiment runs.

KAJIMA et al. (1982) carried out large scale experiments of beach change, using a wave flume ( $205 \mathrm{~m}$ long, $3.5 \mathrm{~m}$ wide, and $6 \mathrm{~m}$ deep) with a piston-type monochromatic wave generator. An initial beach slope was uniform with a gradient of $1 / 20$, and water depth at the horizontal part was $4.5 \mathrm{~m}$. The beach profile was measured along the center line of the flume. For an experiment case ( $T=9.0 \mathrm{sec}, H_{0}=0.95 \mathrm{~m}$, and $D=0.47 \mathrm{~mm}$ ), a typical berm developed from the initial uniform slope. A duration of wave action was sixty-nine and a half hours. Because no measurement of breaker height was made in this experiment, the initial height of breaking waves was calculated from deep-wave characteristics using SUNAMURA and HORIKAWA's (1974) relation ${ }^{2}$.

Berms created in these prototype-scale experiments were reckoned as collapsing related berms, judging from their equilibrium beach profiles. Correlation between the measured berm position and the predicted one using Eq. (7), and correlation between the measured berm height and the predicted one by Eq. (11) are shown in Figs. 6 


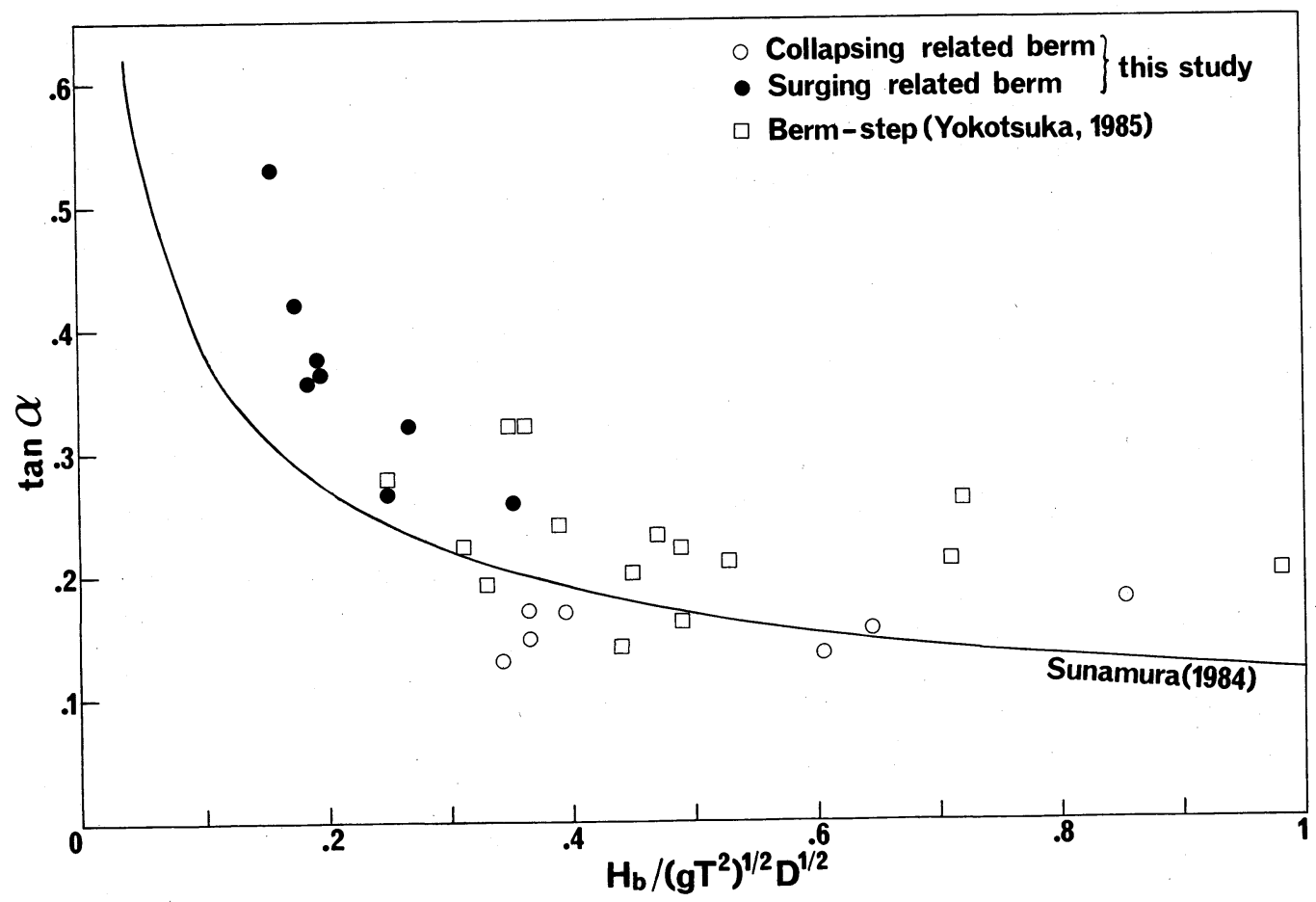

Figure 4. Beach-face slope of berms created in a small-scale wave flume. The solid curve indicates SUNAMURA's (1984) relation.

and 7 , respectively. These two figures indicate that measurement and prediction are in good correlation; this suggests that no scale effect is involved in Eqs. (7) and (11), which may be applied to the field situation.

\section{APPLICATION TO THE FIELD}

\section{Beach profile and sediment size data}

To examine the applicability of Eqs. (7) and (11) to the field, beach profile data will be used, which were obtained at Ajiga-ura Beach, Ibaraki, Japan, by the Public Works Research Institute (PWRI), Ministry of Construction. Ajiga-ura, situated in the southern part of Naka Beach, has an approximately straight, north-south oriented shoreline facing the Pacific Ocean (Fig. 8). At Ajiga-ura Beach a 190-m long observation pier jutting out to the sea, normal to the general shoreline trend, was constructed by PWRI in 1976. The nearshore bottom contour lines run approximately parallel to the shoreline (Fig. 9). The change in nearshore bottom slope from steep to gentle occurs at a water depth of about $10 \mathrm{~m}^{3}$ ) (Fig. 9). The bottom slope is almost constant to $10-\mathrm{m}$ depth and its average is about $1 / 65$.

Beach profiles were measured once a week by PWRI at 80 stations located at 3-m intervals along the pier and landwards on an extended line. The measurement, conducted by using a level, staff and tape in a subaerial zone and by a lead in a submerged zone, was made with reference to the mean sea level at Tokyo Bay. Time-series data of beach profiles measured between February 1976 and December 1989 were summarized by UDA and SAKAI (1985) and UDA et al. (1990).

The grain size of the sediment at Ajiga-ura Beach was investigated from 9 to 22 February 1988 by UDA et al. (1989). According to the result of a sieve analysis of sediment samples collected at two foreshore points, the median diameters were similar to each other, about $0.34 \mathrm{~mm}$, and they were found to be almost constant in relation to time.

The calculation of dimensionless sediment diameter $D_{*}$ in the field, which was made through $D_{*}=240.3 D$ (in $\mathrm{cm}$ units), was obtained by substituting $\rho_{S} / \rho=2.59$ and $v=1.06 \times 10^{-2} \mathrm{~cm}^{2} / \mathrm{sec}$ (at a water temperature of $18^{\circ} \mathrm{C}$ ) into Eq. (2). Since $D=0.34 \mathrm{~mm}=0.034 \mathrm{~cm}$, we have $D_{*}=8.17$; Eq. (4) yields $\phi=0.88$.

\section{Wave data}

Wave measurements have been conducted by the Ministry of Transport at two sites near Ajiga-ura 


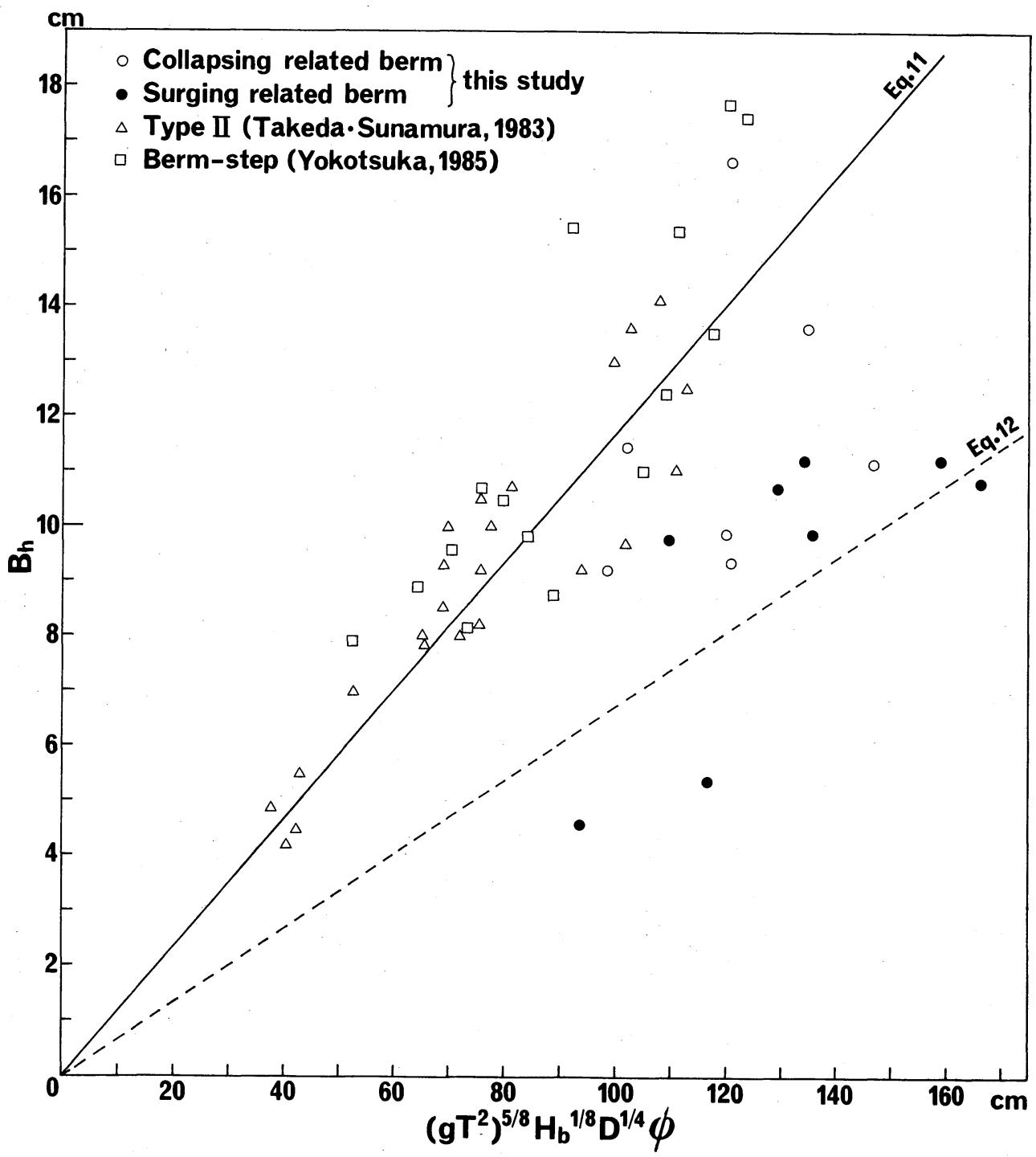

Figure 5. Height of berms created in a small-scale wave flume.

The solid line shows a relation for collapsing related berms and the dashed line for surging related berms.

Beach: one is located $3.7 \mathrm{~km}$ offshore of this beach, where an ultrasonic-type wave gage has been installed at 28-m depth, and the other is located off Kashima Port, about $55 \mathrm{~km}$ south of Ajiga-ura, where the similar type of wave gage has been set up at 21-m depth. Wave data off Kashima Port obtained from 1976 through 1979 and those off Ajiga-ura Beach from 1980 through 1989 will be used for the present analysis of berm data.

The characteristics of mean waves were used in the calculation of the present study. Using Eq. (5), the breaker height $H_{b}$ at Ajiga-ura Beach was estimated ${ }^{4}$. The breaker height and period of mean waves were averaged over a period during which the beach changed from the initial smooth profile to a near-equilibrium berm profile.

TAKEDA and SUNAMURA (1982) examined the applicability of their predictive relation on berm height to the field using significant waves, the highest one third of waves ${ }^{5}$. According to SAWARAGI $(1982$, p. 56), the ratio of run-up height to the significant wave height decreases with decreasing beach slope in comparison with that of run-up height to the monochromatic wave height, so that use of significant waves in TAKEDA and SUNAMURA (1982) seems to be unsuitable. 

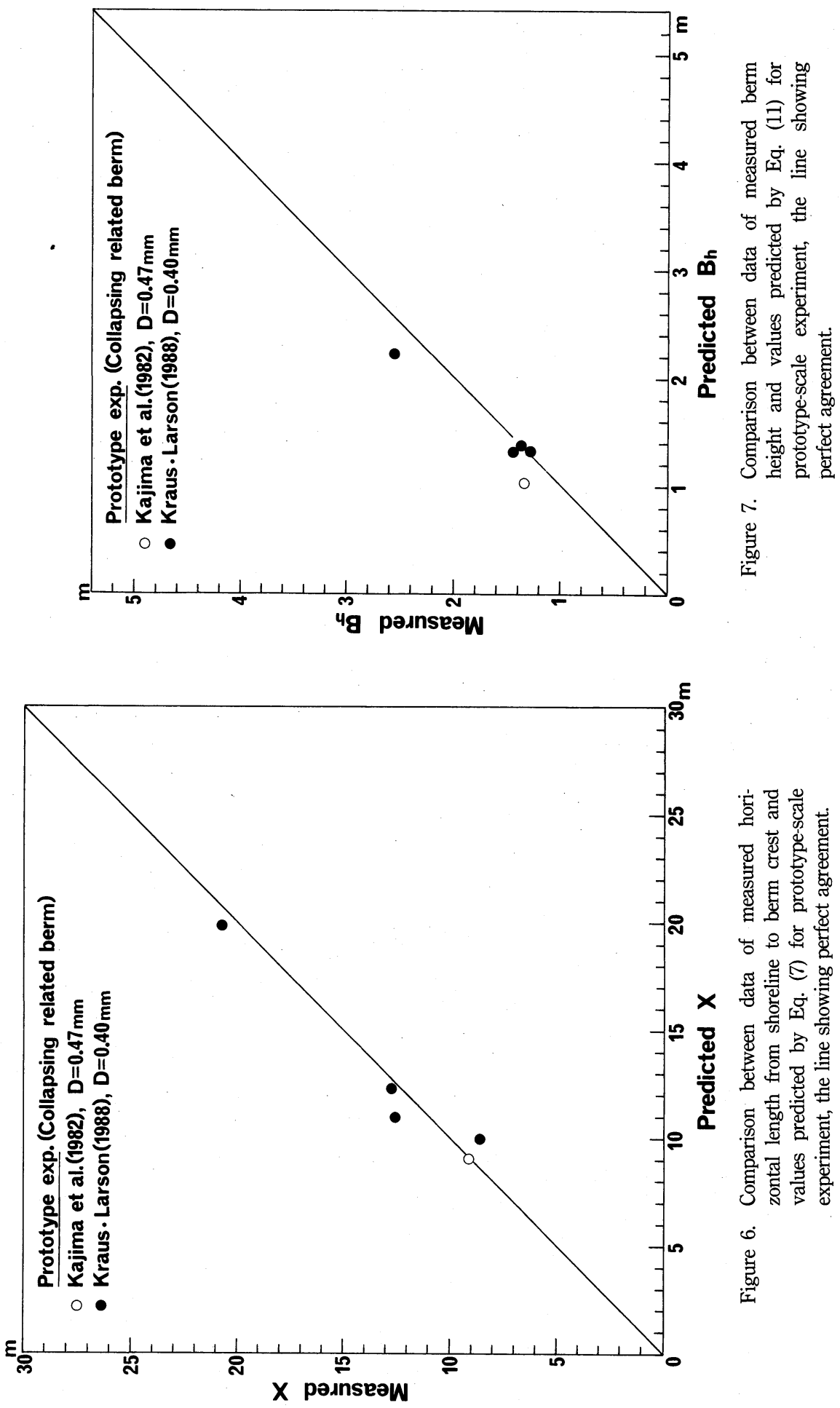


\section{Tides}

In TAKEDA and SUNAMURA (1982) no attention was paid to the effect of tidal ranges on the berm height in the field. Because the berm crest was usually formed by

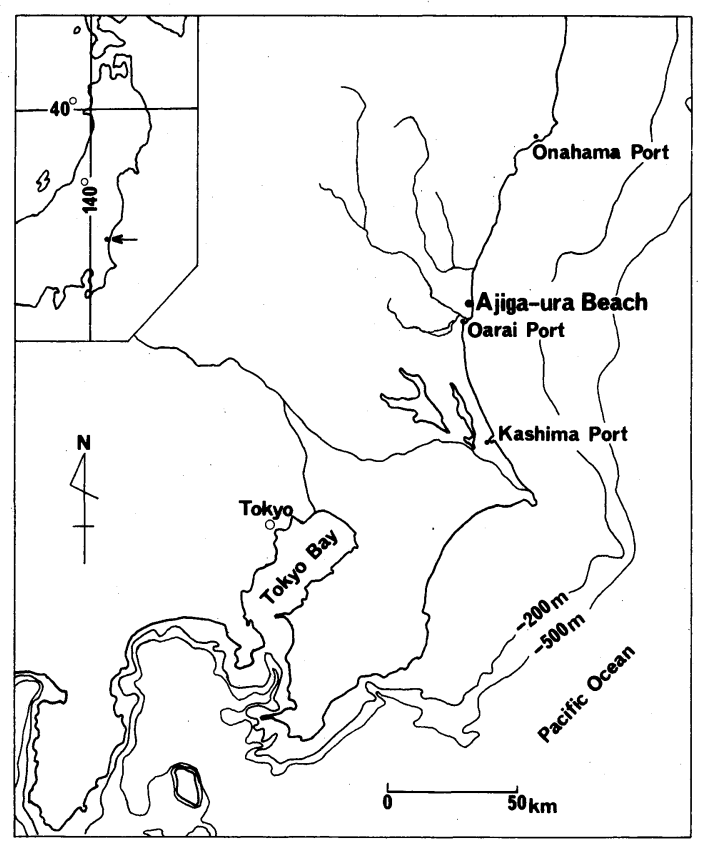

Figure 8. Location map.

Ajiga-ura Beach is the site where field data were obtained by PWRI. waves at high waters, the tidal range is of importance. Tides at Oarai Port, close to Ajiga-ura Beach, are mixed with a maximum range of $150 \mathrm{~cm}$ and a minimum range of $10 \mathrm{~cm}$ (Japan Meteorological Society, 1991, pp. 62-67). The mean height of high waters at new and full moons above mean sea level was averaged over one year: $57.2 \mathrm{~cm}$ at Oarai Port (Japan Meteorological Society, 1991, pp. 62-67).

The mean sea level, average over six years from 1980 to $1985^{6}$ ), at Onahama Port located $66.5 \mathrm{~km}$ north of Ajiga-ura Beach is $4.5 \mathrm{~cm}$ lower than the mean sea level at Tokyo Bay, i.e., T.P. The level of $52.7 \mathrm{~cm}$ high above T.P. was selected here as a reference level when the berm position and height were measured; this level is referred to as "HWL", and the shoreline at HWL as "HW shoreline".

\section{Results}

The beach profile immediately after the attack of storm waves was smooth and uniformly sloping seawards. Under favorable wave conditions, berms started to form in several days. Figure 10 shows an example of the beach profile change during the period of six weeks from November 10th to December 22nd in 1983. Figure 11 shows the temporal change in wave conditions for this period; in this figure, $H_{*}$ and $T_{*}$ denote daily average values of mean wave height and period, respectively.

As exemplified in Fig. 11, the mean height of storm waves tends to exceed about $3 \mathrm{~m}$ at Ajiga-ura Beach.

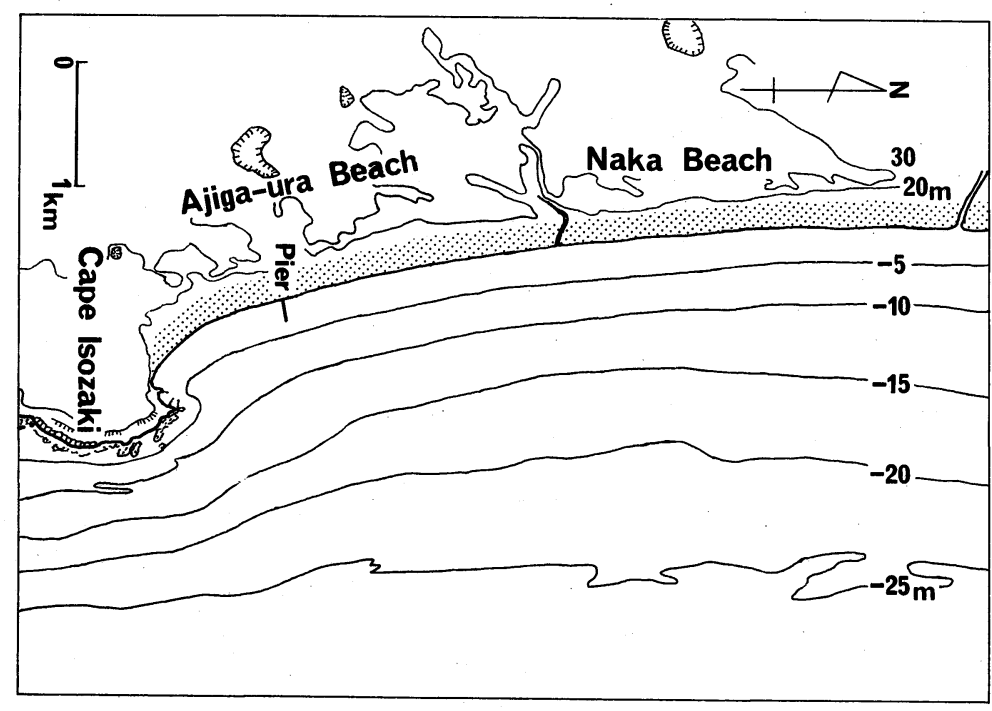

Figure 9. Ajiga-ura Beach and the observation pier of PWRI. Nearshore bottom contour lines are after TAKEDA (1984). 


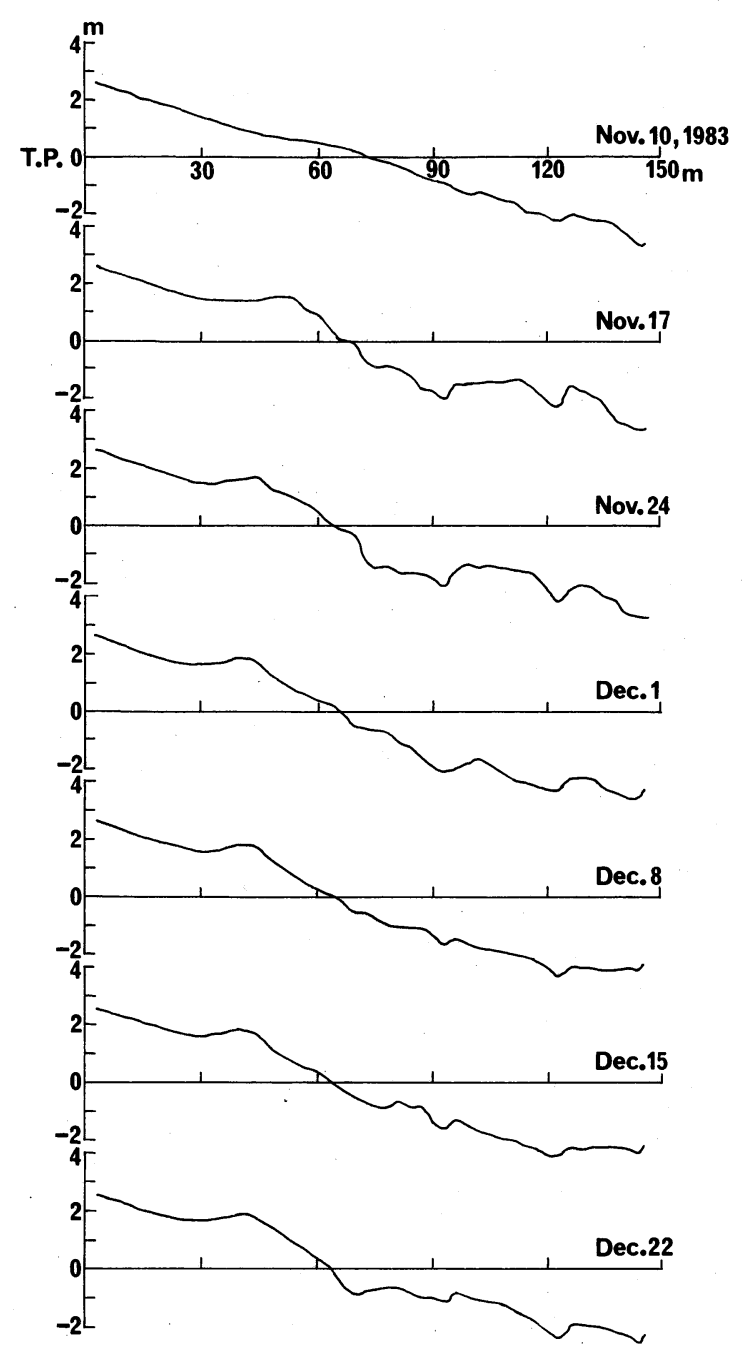

Figure 10. Example of berm development after the attack of storm waves at Ajiga-ura Beach. Data from PWRI.

Figures 12 and 13 show some examples of the temporal change in the berm height above T.P. About three weeks were required for the berm to attain equilibrium at Ajiga-ura Beach.

Berms, the development of which continued over about three weeks as shown above, were treated in the present study. Berms which fulfilled this condition occurred eleven times from February 1976 through December 1989 (Table 2). Most of the berms formed during this period were found to fall into the category of collapsing related berms, judging from their growth pattern (OKAZAKI, 1994). Berm formation occurred more frequently in the summer at Ajiga-ura Beach.

The breaker height, $\bar{H}_{b}$, and wave period, $\bar{T}$, of mean waves averaged over the period of berm development were substituted, respectively, for $H_{b}$ and $T$ in Eqs. (7) and (11). Figure 14 shows the relationship between the horizontal length measured from the HW shoreline to the berm crest, which is denoted as $X^{\prime}$, and $\left(g \bar{T}^{2}\right)^{3 / 8} H_{b}^{5 / 8} \phi$, in which $\phi=0.88$ was employed as described before. Although considerable scatter in data points is seen, the solid line connecting the origin of the graph and the center of a cluster of the data points can be written as

$$
X^{\prime} /\left(g T^{2}\right)^{3 / 8} H_{b}^{5 / 8} \phi=1.14
$$

Large data scatter is probably due to temporal changes in (1) tidal range, (2) incident wave characteristics, and (3) groundwater level of the beach (DUNCAN, 1964). Another reason is inaccuracy in the determination of water level: minor error in the vertical scale gives rise to large difference in the horizontal distance to the berm crest.

The prediction by Eq. (7) obtained in the laboratory under monochromatic wave conditions is also plotted by a dashed line in this figure. The coefficient in Eq. (13) is 1.9 times greater than that of Eq. (7). A possible reason for this large deviation is that waves with larger height and longer period than mean waves facilitate significant landward migration of the berm crest.

The berm height measured from HWL, $B_{h}^{\prime}$, is plotted against $\left(g \bar{T}^{2}\right)^{5 / 8} \bar{H}_{b}^{1 / 8} D^{1 / 4} \phi$ with $\phi=0.88$ on Fig. 15 . Although the data points are widely scattered, the following equation is reasonable to describe the berm height in the field:

$$
B_{h}^{\prime} /\left(g \bar{T}^{2}\right)^{5 / 8} \bar{H}_{b}^{1 / 8} D^{1 / 4} \phi=0.134
$$

The prediction by Eq. (11) obtained under conditions of monochromatic waves in the laboratory is also plotted by a dashed line in this figure. The coefficient of Eq. (14) is only 1.15 times greater than that in Eq. (11), which is much smaller as compared with the case of berm position. This suggests that the berm height may be approximately controlled by mean waves.

\section{CONCLUSIONS}

In an equilibrium state, the position of berms created in a small-scale wave flume is given by Eqs. (7) and (8), respectively, for collapsing and surging related berms. The berm height is also predicted by Eqs. (11) and (12), respectively, for collapsing and surging related berms. These equations involve the reduction factor due to the roughness and permeability of the beach, which 

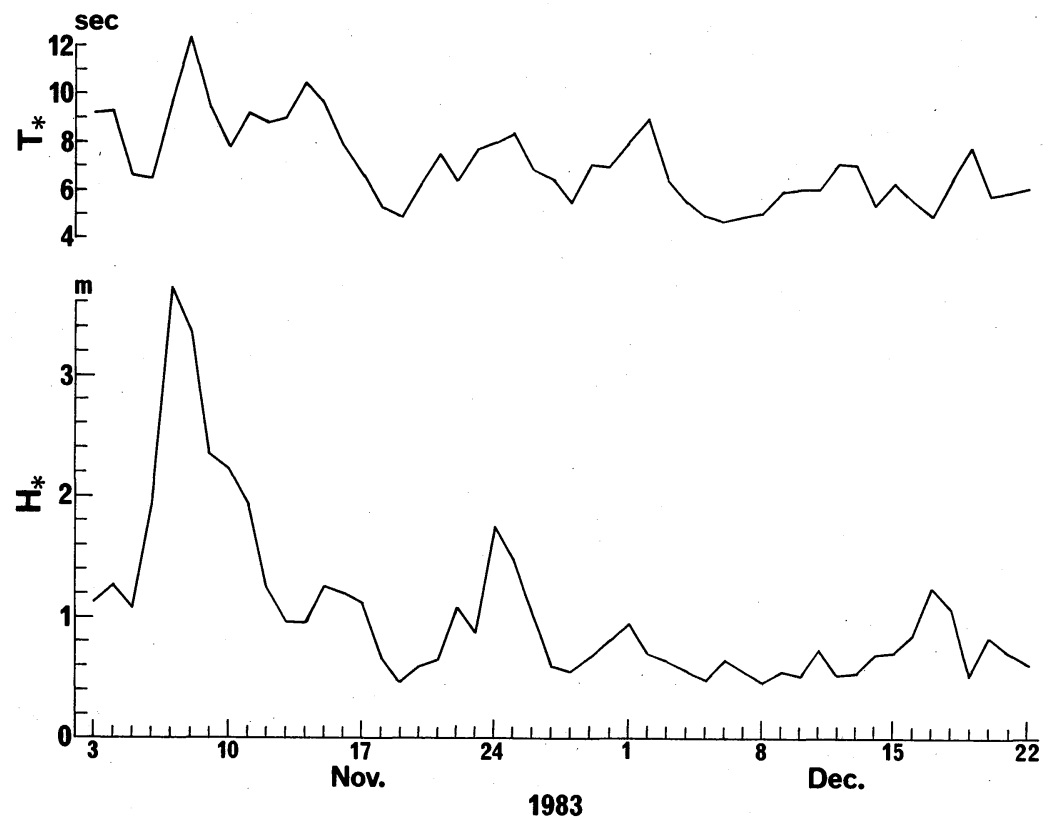

Figure 11. Time-series data of daily average period and height of mean waves in the offshore zone at Ajiga-ura Beach during the same period as described in Fig. 10.

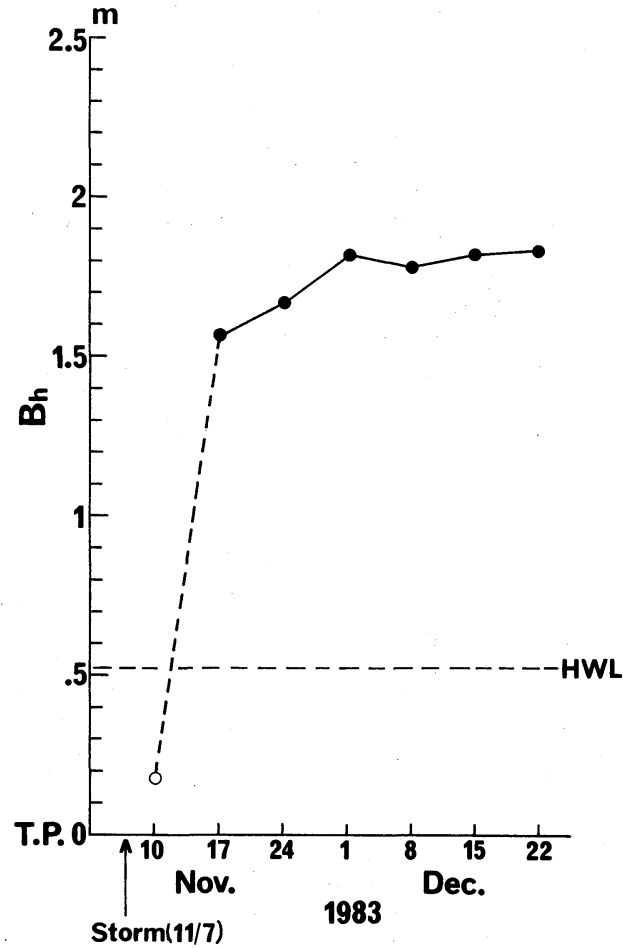

Figure 12. Temporal change in the height of a berm illustrated in Fig. 10 Data from PWRI. is described by Eq. (4). Analyses of prototype-scale experiment data indicate that no scale effect is involved in Eqs. (7) and (11).

Using time-series data of the beach profile, applicability of these equations to the field situation was examined. Considering the effect of tidal ranges on the berm formation, the measured values were corrected: the height of the mean high waters (HW) was used as a reference level. The breaker height and wave period of mean waves averaged over the period of berm development were substituted respectively for the wave characteristics of Eqs. (7) and (11). The result shows that the berm position measured from HW shoreline is given by Eq. (13) and the berm height above HWL is expressed by Eq. (14).

\section{Acknowledgments}

The authors wish to express their thanks to the Yokohama Investigation and Design Office, Ministry of Transport, for allowing them to use wave data. Part of this study was made under the Grant-in-Aid for Scientific Research of the Ministry of Education, Science and Culture of Japan (No. 04452329) given to TS.

(Received Aug. 31, 1994) (Accepted Oct. 15, 1994) 

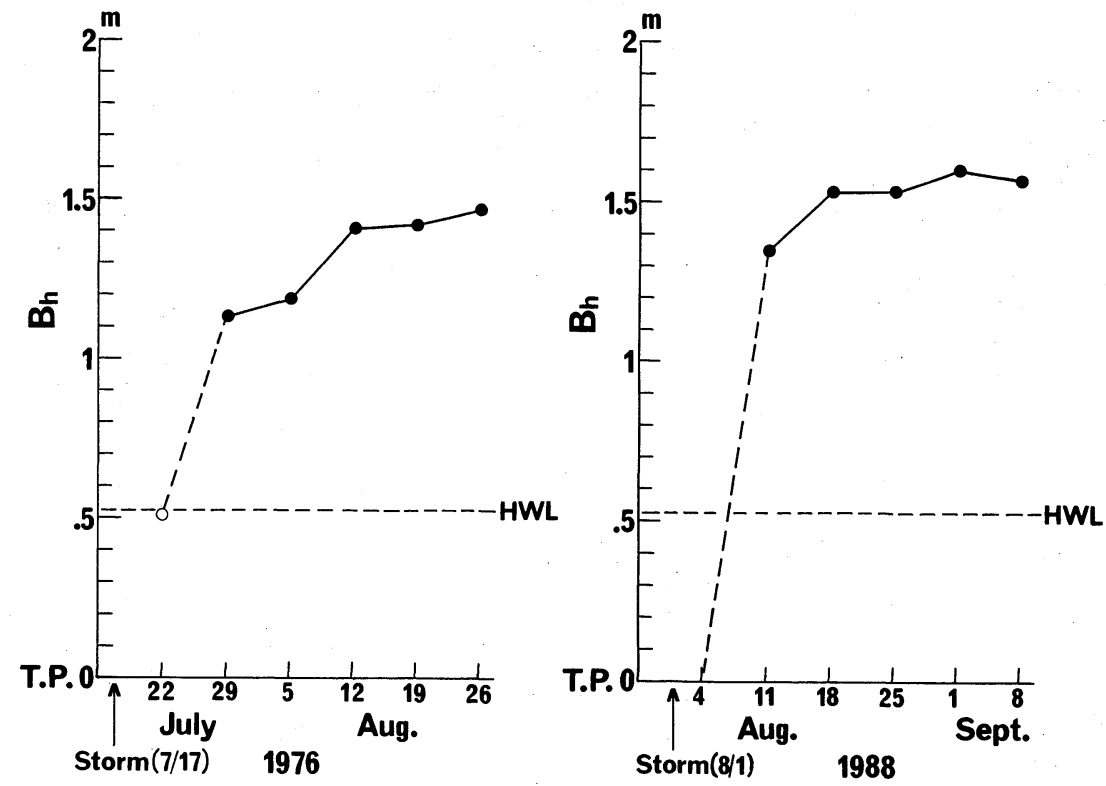

Figure 13. Examples of temporal change in the height of berms formed at Ajiga-ura Beach. Data from PWRI.

Table 2. Field data at Ajiga-ura Beach.

\begin{tabular}{lcccc}
\hline \hline Period of berm formation & $\begin{array}{c}\bar{H}_{b} \\
(\mathrm{~m})\end{array}$ & $\begin{array}{c}\bar{T} \\
(\mathrm{sec})\end{array}$ & $\begin{array}{c}X^{\prime} \\
(\mathrm{m})\end{array}$ & $\begin{array}{c}B_{h}^{\prime} \\
(\mathrm{m})\end{array}$ \\
\hline July 22 Aug. 12, 1976 & 0.78 & 6.9 & 10.0 & 0.86 \\
Apr. 20 May 25, 1978 & 1.03 & 6.5 & 16.1 & 0.83 \\
Mar. 1 Mar. 22, 1979 & 2.53 & 8.1 & 12.8 & 0.79 \\
Oct. 30 Nov. 20, 1980 & 1.09 & 6.9 & 10.6 & 0.75 \\
July 8 July 29, 1982 & 1.37 & 7.1 & 16.8 & 0.83 \\
Aug. 5 Aug. 26, 1982 & 1.07 & 7.3 & 17.8 & 0.76 \\
Nov. 10 Dec. 1, 1983 & 1.42 & 7.5 & 15.9 & 1.29 \\
Apr. 4 Apr. 25, 1985 & 2.01 & 7.6 & 6.4 & 0.81 \\
July 9 July 30, 1987 & 1.15 & 7.4 & 12.2 & 0.69 \\
Oct. 1 Oct. 22, 1987 & 1.69 & 7.5 & 17.2 & 0.94 \\
Aug. 4 Aug. 25, 1988 & 1.32 & 7.3 & 1.04
\end{tabular}

$\bar{H}_{b}$ : Breaker height of mean waves, $\bar{T}$ : Period of mean waves, $X^{\prime}$ : Berm position measured from HW shoreline, and $B_{h}^{\prime}$ : Berm height above HWL.

\section{Notes}

1) Data of the beach profile for TAKEDA and SUNAMURA (1982) were described in TAKEDA and SUNAMURA (1983). The duration of wave action of their experiment was one hour for each run, which seems to be enough for the achievement of an equilibrium state of beach profile in the small-scale wave flume.

2) SUNAMURA and HORIKAWA's (1974) relation concerning the breaker height on a uniform slope for monochromatic waves is as follows: $H_{b} / H_{0}=(\tan \beta)^{1 / 5}\left(H_{0} / L_{0}\right)^{-1 / 4}$. This relation was confirmed by SUNAMURA (1982) to be applicable to prototype-scale wave-tank experiments.
3) According to UDA and NoGUCHI (1990), the critical water depth for sediment movement on open coasts facing the Pacific Ocean in Japan is 8 to $10 \mathrm{~m}$. Bottom contours shallower than this critical depth are similar to the shoreline configuration and are approximately parallel to each other.

4) Concerning the breaker height in the field, WEISHAR and BYRNE (1978) obtained the following relationship: $H_{b} / H_{0}=0.52\left(H_{0} / L_{0}\right)^{-1 / 5}$. This result indicates that Eq. (5) provides a reasonable estimation of breaker height in the field. During their observation the wave period was about 8 seconds and the nearshore bottom slope was about $1 / 50$. These surf conditions are similar to those at Ajiga-ura Beach. 

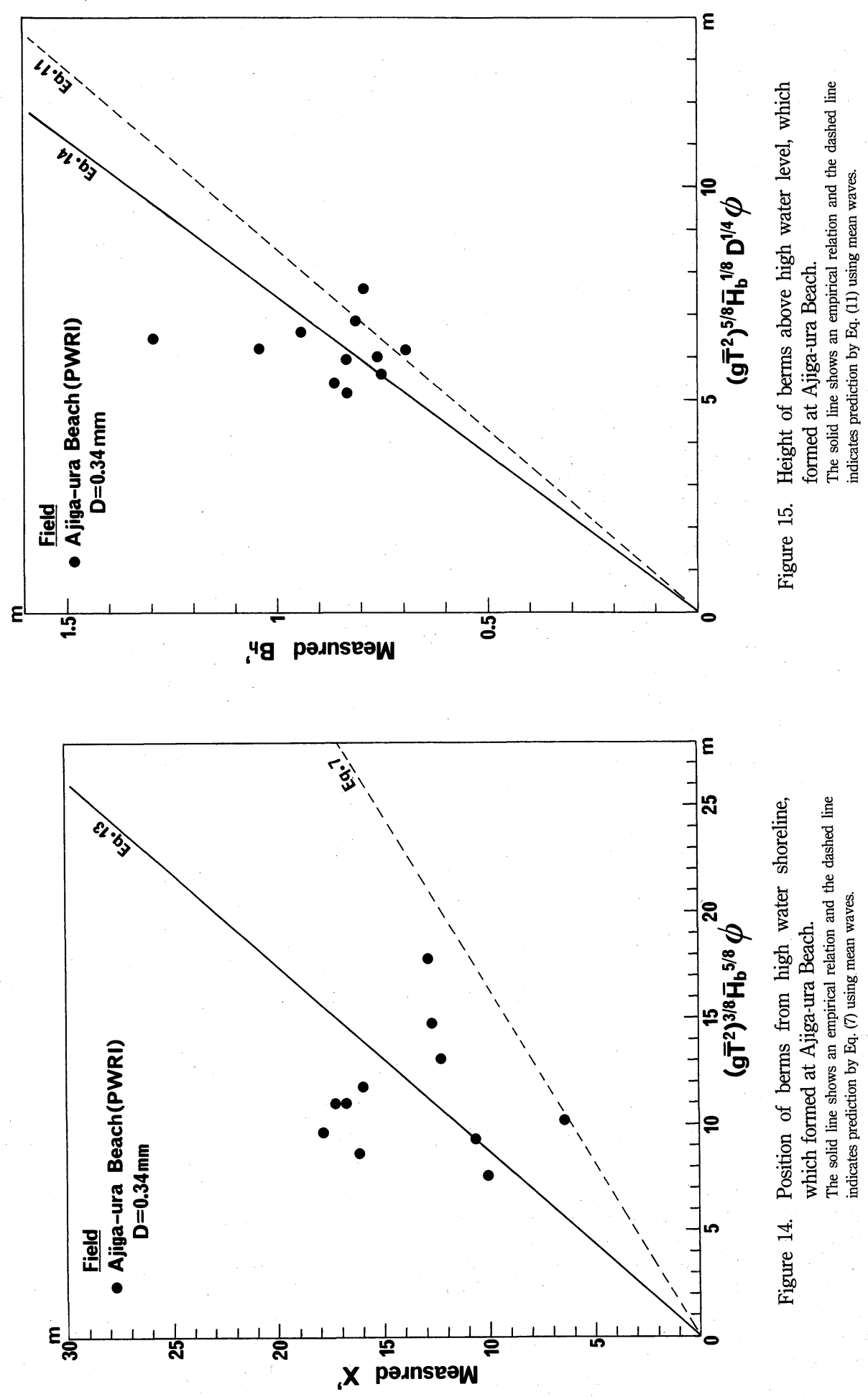
5) They selected a period when $\sigma_{H} / \bar{H}_{b 1 / 3}<0.3\left(\sigma_{H}\right.$ is standard deviation and $\bar{H}_{b 1 / 3}$ is average breaker height of significant waves) and used average values of wave characteristics during the period.

6) Data of mean sea level were after "Tidal Observations, Ser. 5" published by Japan Meteorological Agency.

\section{References}

ACKERS, P. and WHITE, W. R. (1973): Sediment transport: New approach and analysis. Journal of the Hydraulics Division, Proceedings of the American Society of Civil Engineers, 99, 2041-60.

BAGNOLD, R. A. (1940): Beach formation by waves; some model-experiments in a wave tank. Journal of the Institution of Civil Engineers, 15, 27-52.

BASCOM, W. N. (1953): Chracteristics of natural beaches. Proceedings of 4th Coastal Engineering Conference, Council on Wave Research, 163-180.

Duncan, J. R. Jr. (1964): The effects of water table and tide cycle on swash-backwash sediment distribution and beach profile development. Marine Geology, 2, 186-197.

GALVIN, C. J. Jr. (1968): Breaker type classification on three laboratory beaches. Journal of Geophysical Research, 73, 3651-59.

HuNT, I. A. (1959): Design of seawall and breakwaters. Journal of the Waterways and Harbors Division, Proceedings of the American Society of Civil Engineers, 85, 123-152.

Japan Meteorological Society (1991): Tide tables in Kanto district for the year 1992.86 p. (J)

KaJMA, R., ShImizU, T., MARUYAMA, K. and SAITO, S. (1982): Experiments on beach profile change with a large wave flume. Proceedings of 18th Coastal Engineering Conference, American Society of Civil Engineers, 1385-1404.

KING, C. A. M. (1959): Beaches and coasts. Edward Arnold, London, $403 \mathrm{p}$.

KOMAR, P. D. and GAUGHAN, M. K. (1972): Airy wave theory and breaker wave height prediction. Proceedings of 13th Coastal Engineering Conference, American Society of Civil Engineers, 405-418.

KRAUS, N. C. and LARSON, M. (1988): Beach profile change measured in the tank for large waves 1956-1957 and 1962 US Army Corps of Engineers, Coastal Engineering Research Center, Technical Report, No. 88-6,163p.

LARSON, M. (1988): Quantification of beach profile change. Department of Water Resources Engineering, Institute of Science and Technology, University of Lund, Report, No. 1008, $293 \mathrm{p}$.

OKAZAKI, S. (1994): An experimental study on the formation of berms and the behavior of standing waves. Transactions, Japanese Geomorphological Union, 15, 53-65.

RECTOR, R. L. (1954): Laboratory study of equilibrium profiles of beaches. US Army Corps of Engineers, Beach Erosion Board, Technical Memorandum, No. 41, 38p.

SAVAGE, R. P. (1958): Wave run-up on roughened and permeable slopes. Journal of the Waterways and Harbors Division, Proceedings of the American Society of Civil Engineers, Paper, No. $1640,38 \mathrm{p}$.

SAVAGE, R. P. (1959): Laboratory data on wave run-up on roughened and permeable slopes. US Army Corps of Engineers, Beach Erosion Board, Technical Memorandum, No. 109, $28 \mathrm{p}$.

SAWARAGI, T. (1982): Littoral drift and beach erosion. Morikita Shuppan, Tokyo, 195 p. (J)

SHIELDS, A. (1936): Anwendung der Aehnlichkeitsmechanik und der Turbulenzforschung auf die Geschiebebewegung. Mitteilungen der Preußischen Versuchsanstalt für Wasserbau und Schiffbau, No. 26, 26p.

SUNAMURA, T. (1975): A study of beach ridge formation in laboratory. Geographical Review of Japan, 48, 761-767.

SuNAMURA, T. (1982): Determination of breaker height and depth in the field. Annual Report of the Institute of Geoscience, University of Tsukuba, 8, 53-54.

SUNAMURA, T. (1984): Quantitative predictions of beach-face slopes. Geological Society of America Bulletin, 95, 242-245.

SunAmuRA, T. and HoRIKAWA, K. (1974): Two-dimensional beach transformation due to waves. Proceedings of 14th Coastal Engineering Conference, American Society of Civil Engineers, 920-938.

TAKEDA, I. (1984): Beach changes by waves. Science Reports of the Institute of Geoscience, University of Tsukuba, Section A, 5, 29-63.

TAKEDA, I. and SUnAMURA, T. (1982): Formation and height of berms. Transactions, Japanese Geomorphological Union, 3, 145-157. (JE)

TAKEDA, I. and SUNAMURA, T. (1983): A wave-flume experiment of beach steps. Annual Report of the Institute of Geoscience, University of Tsukuba, 9, 45-48.

TERADA, M. (1976): On the wave run-up after breaking on the beach at Hiratsuka, Kanagawa Prefecture. Geographical Review of Japan, 49, 550-561. (JE)

TsuchiYA, Y., KaWATA, Y. and YASHITA, T. (1978): Effect of roughness and permeability on wave run-up. Proceedings of 25th Coastal Engineering Conference in Japan, Japan Society of Civil Engineers, 160-164. (J)

UDA, T. and NoGUCHI, K. (1990): Beach changes on the Miyazaki and Sakai Coasts in Toyama Prefecture, Japan. Transactions, Japanese Geomorphological Union, 11, 337-347. (JE)

UDA, T. and SAKAI, Y. (1985): Summarized data of beach profiles and wave observations at Ajigaura Beach. Technical Memorandum of Public Works Research Institute, Ministry of Construction of Japan, No. 2294, 286p.

UDA, T., OMATA, A. and TAKEBUCHI, T. (1989): Dominant factors determining foreshore changes and processes of berm formation. Proceedings of the Japan Society of Civil Engineers, 411, II-12, 227-236. (JE)

UDA, T., ITO, H. and SAITO, T. (1990): Summarized data of beach profiles and wave observations at Ajigaura Beach (2). Technical Memorandum of Public Works Research Institute, Ministry of Construction of Japan, No. 2900, 438p.

WEISHAR, L. L. and BYRNE, R. J. (1978): Field study of breaking wave characteristics. Proceedings of 16th Coastal Engineering Conference, American Society of Civil Engineers, 487-506.

YALIN, M. S. (1977): Mechanics of sediment transport, 2nd ed. Pergamon Press, Oxford, 298p.

YALIN, M. S. and RuSSELL, R. C. H. (1962): Similarity in sediment transport due to waves. Proceedings of 8th Coastal Engineering Conference, Council on Wave Research, 151-167.

YoKOTsUKA, Y. (1985): A wave-tank study on topographical 


\title{
バームの位置と高さに関する定量的予測
}

\author{
岡崎清市 $*$. 砂村継夫 $* *$
}

平衡時のバームの位置と高さに関して, まず小型造波 水路における実験結果から予察的な関係式を導いた。汀 線からバーム・クレストまでの水平距離として定義され たバームの位置 $X$ は, $X /\left(g T^{2}\right)^{3 / 8} H_{\mathrm{b}}^{5 / 8} \phi=0.605$ (collapsing 型バームの場合), 0.305 (surging型バームの場合) で与 えられる。ここに, $H_{\mathrm{b}}$ は初期の砕波波高, $g$ は重力加速 度, $T$ は波の周期, $\phi$ は海浜堆積物の粗度と透水性に依 存する減少係数である。減少係数は, 無次元粒径 $D_{*}$ を 用いて $\phi=\exp \left(-0.04 D_{*}^{0.55}\right)$ により与えられる。ここ $D_{*}=$ $\left[g\left(\rho_{\mathrm{s}} / \rho-1\right) / v^{2}\right]^{1 / 3} D, \rho_{\mathrm{s}}$ は堆積物の密度, $\rho$ は流体密度, $v$ は動粘性係数, $D$ は底質粒径である。バームの高さ $B_{\mathrm{h}}$ は 次式により与えられる。すなわち $B_{\mathrm{h}} /\left(g T^{2}\right)^{5 / 8} H_{\mathrm{b}}{ }^{1 / 8} D^{1 / 4} \phi=$ 0.117 (collapsing型バームの場合), 0.067 (surging型バ
ームの場合)。原型規模での実験結果によれば, collapsing型バームの位置と高さの関係式にはスケール効果は 含まれていない。

次にこれらの式に野外における適用性を，茨城県阿字 ヶ浦海岸における実測データで検討した。朔望平均満潮 位（HW）を基準位として，バームの位置と高さをそれ ぞれ求めた。バーム形成期間中における平均波の砕波波 高 $\bar{H}_{\mathrm{b}}$ と周期 $\bar{T}$ のれぞれが，これら 2 式の波の諸元と 置き換えられた。HWの汀線から測ったバームの位置 $X^{\prime}$

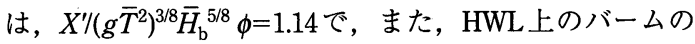
高さ $B_{\mathrm{h}}{ }^{\prime}$ は, $B_{\mathrm{h}}{ }^{\prime} /\left(g \bar{T}^{2}\right)^{5 / 8} \bar{H}_{\mathrm{b}}{ }^{1 / 8} D^{1 / 4} \phi=0.134$ でそれぞれ表せる ことが判った。 